\title{
The Seventh International Congress of Photography.
}

'THE seventh International Congress of Photography was held in London on July 9-14, a period of three years having elapsed since the last Congress was held in Paris, in June 1925. The Royal Photographic Society, which is the premier photographic society of the world, made itself responsible for all the arrangements, and about twelve months ago it started the work of preparation, an organising committee being appointed which comprised representatives not only of photographic societies and associations, but also of the various scientific societies of Great Britain. The chairman of this committee was Sir William Pope, and the secretary, Dr. W. Clark.

As in the case of previous congresses, the seventh consisted of three sections, dealing respectively with : (1) Scientific and Technical Questions, (2) Pictorial Photography, (3) Bibliography, Record Photography, History, ete. Section (1) was divided into four subsections, dealing respectively with $(a)$ Theoretical Aspects of Photography, (b) Photographic Practice, (c) Scientific Applications of Photography, and (d) Industrial and other Special Applications of Photography. The mere names of the sections and subsections indicate the wide scope of the subjects under consideration, although it hides such important applications as kinematography, colour photography, and photo-engraving processes, which were included under I $(d)$. Special committees were in charge of each section and sub-section, and well-known workers in the different subjects in various parts of the world. were invited to send in communications. As a result, some seventy papers were received from workers in England, the United States, Germany, France, Italy, and Switzerland, so that copious material was received for discussion at the various sectional meetings.

The meetings were held at the Imperial College of Science and Technology, South Kensington, and the Congress was opened on the morning of July 9 by Sir William Pope, who had been elected president. A large and representative gathering of workers associated with the science of photography, including delegates from the United States, France, Germany, Belgium, Italy, Switzerland, and Russia, was present, and the president was supported on the platform by M. L. P. Clere (France), Prof. R. Luther (Germany), M. Callier (Belgium), Dr. C. E. K. Mees (America), and Mr. F. F. Renwick and Dr. T. Slater Price (Royal Photographic Society). The president, after welcoming the delegates from overseas, referred to the progress achieved since the days of the first international congress, held in Paris in 1889, and to the services rendered by photography in everyday life, as, for example, in the daily and illustrated Press. More particularly he emphasised the inereasing importance of photography in its scientific applications. Whole branches of modern science are founded on photographic methods and depend for their existence on photographic aid : examples may be given in the methods of X-ray crystal analysis introduced by Sir William Bragg, and thể spectroscopic study of the aurora borealis. Again, photography is an indispensable instrument in working out the conclusions of modern physics. In another direction kinematography is a popular triumph of photography, with the promise of coming new developments in talking films and films in natural colour. The president finally referred to the fact that modern photography depends mainly on the sensitiveness of silver salts, and suggested that investigation of other substances, which are known to be light-sensitive, might reveal other possibilities of practical application to photographic use.
The president then declared the Congress open, and invited the members, before the sessions of the various sections opened in the afternoon, to visit a new feature of these international congresses, namely, an exhibition of examples of nature photography, photographic survey and record work, photo-micrography and colour photography in the shape of both transparencies and prints, scientific photographs and apparatus, etc. There was also a collection of examples from British and American workers of commercial and advertising photography ; in addition, many trade firms, British, American, and German, had exhibits.

Following the usual custom, the various sectional meetings, at which the proceedings were conducted in either English, French, or German, were presided over in turn by delegates chosen from the various countries represented. As can be seen from the list published in. NATURE of June 23, p. 1007, the papers even in each section extended over a wide range of subjects. In many cases they gave rise to lively discussions, but their full value will only be appreciated after they, together with the discussions, have been collected together and printed in the Proceedings of the Congress. It may be said, however, that the riddle of photographic sensitivity and of the latent image still seems to be very far from solution. It was hoped that one of the chief objects of the Congress would be achieved, namely, the standardisation of sensitometric measurements. At the Paris Congress various recommendations of the English committee were accepted (see NATURE, 116, 224; 1925), but were only to come into force after a period of six months if they were not objected to by any national committee. Objections were raised, however, by the committee of the Optical Society of America, more particularly with respect to the standard light source to be used, with the result that international agreement was still wanting. At the present Congress the American Committee put forward definite proposals with respect to the standard of photographic light intensity. These gave rise to a lively and animated discussion, but since they had been sent in too late for them to receive due consideration from the other national committees, it was not possible to come to a definite decision at once. The following resolution was, however, passed. It is given here because of its importance to all users of the photographic plate in scientific investigations, and it is hoped that any reader interested will send criticisms to the secretary of the National Committee on Standardisation, Dr. Slater Price.

"This meeting of the 7th International Congress recommends to the National Committees that the photographic unit of intensity for the sensitometry of negative materials shall be defined as the intensity of a source of radiation having a luminous intensity of one international candle, and produced by a grey body at a colour temperature of $2360^{\circ} \mathrm{K}$., together with a selectively absorbing filter made up as follows : Two solutions compounded according to the following formula, the complete filter to consist of a one-cm. ${ }^{1}$ layer of each solution contained in a double cell made by using three plates of borosilicate crown glass (refractive index, $\mathrm{D}$ line $=1 \cdot 51$ ), $2.5 \mathrm{~mm}$. thick.

\section{Solution A.}

Copper sulphate $\left(\mathrm{CuSO}_{4}, 5 \mathrm{H}_{2} \mathrm{O}\right)$

Mannite $\mathrm{C}_{6} \mathrm{H}_{8}(\mathrm{OH})_{6}$

Pyridine $\left(\mathrm{C}_{5} \mathrm{H}_{5} \mathrm{~N}\right)$

Water (distilled) to make

3.707 grm.
$3 \cdot 707$ grm.
$30 \cdot 0$ c.c.
$1000 \quad$ c.c.

1 Tolerance in thickness shall be $\pm 0.05 \mathrm{~mm}$.

2 For practical purposes an accuracy to the second place of decimals is probably sufficient.

No. 3067, VoL. 122] 


\section{Solution B.}

Cobalt ammonium sulphate

$\left(\mathrm{CoSO}_{4},\left(\mathrm{NH}_{4}\right)_{2} \mathrm{SO}_{4}, 6 \mathrm{H}_{2} \mathrm{O}\right)$

Copper sulphate $\left(\mathrm{CuSO}_{4}, 5 \mathrm{H}_{2} \mathrm{O}\right)$

Sulphuric acid (Sp. gr. 1.835)

Water (distilled) to make

In addition to the various meetings of the sections there were three special lectures which members of the Congress were invited to attend. These were : "Pictorial Photography: the Relation of Technical Advance to Further Artistic Achievement," by F. C. Tilney; The Hurter and Driffield Memorial Lecture, by Dr. S. E. Sheppard, who took the latent image as his subject; and "Physies in Photography," by Dr. C. E. K. Mees. The first two were held at the Royal Photographic Society, and the last, at the invitation of, and in co-operation with, the Institute of Physies, at the Institution of Electrical Engineers. There were also motor-coach excursions to places of interest, visits to such places as the Elstree Studios, Amalgamated Press, Northcliffe House, etc. Of course there was the usual banquet, which was held on the Wednesday evening, July 11, with the president in the chair.

Especial mention should be made of the collection of British pictorial photographs and photographs of pictorial and historical interest, which was exhibited at the Royal Photographic Society, and of historical photographic apparatus exhibited at the Science Museum, South Kensington. Apart from members of the Royal Photographic Society, most people in Britain are unaware of the valuable historic collections, both of photographs and apparatus, which are to be found in the rooms of the Royal Photographic Society.

The final meeting of the Congress was held on Saturday morning, July 14. Sir William Pope was unanimously elected the president of the Permanent Committee of International Congresses of Photography, while Dr. Clark, according to precedent, was elected general secretary of the Permanent Committee. An invitation was received from the German delegates to hold the next Congress in Dresden in 1931 ; this was unanimously accepted. The opinion expressed by the foreign delegates was that the Congress wais the most successful which had ever been held and that a standard had been set which it would be difficult to maintain. One very noticeable feature of the Congress was the cordiality prevailing between the delegates of the various nationalities present. Although agreement could not be reached upon all questions of standardisation, much was gained in social intercourse and private discussions, all of which will have its effect in future congresses.

\section{The Great Perseid Meteor Shower.}

THIS shower comes this year under rather favourable conditions, the moon being a mere crescent and not capable of interference with the display. In 1921, on Aug. 12, there was a brilliant exhibition of the meteors at about 2.30 A.M. This corresponds to Aug. 11, 1928, 9 P.м. There should be many meteors, therefore, in the evening, though the fact that the radiant is low will operate against a plentiful shower.

It will be important to notice the horary rate of appearance of the meteors, so that the time of maximum and its strength may be ascertained. The apparent paths of all the brighter meteors should be recorded accurately for the purpose of affording data for the computation of their real paths in the air. Those of the meteors which are directed in their flights from other systems than the Perseids should be specially registered, for more investigation of the secondary showers of this period is needed.

There are already many Perseid observations, and the drifting radiant has also been fully discussed. Its duration seems to extend from June 25 to Sept. 5, and the motion of its radiant is directed from $356^{\circ}+39^{\circ}$ to $92^{\circ}+62^{\circ}$ during the 72 days.
This shower is one of the oldest recorded in historic annals, for its initial mention is dated A.D. 714. Yet more than 1000 years elapsed before the month was specially recognised as a notable one for its meteors. The early returns of the display occurred in July, but the effects of precession have carried it forward until at the present time its chief exhibition comes on Aug. 11.

The parent comet, 1862 III, discovered independently by Tuttle and Swift in America, is a periodical one with a time of revolution about 120 years. The period of the meteors is doubtful, but there are indications of 105 years, answering to some of the best of the ancient and modern displays. I investigated the records, and found a shorter period advisable, namely, 11.72 years, which shows a singular agreement with many of the brighter and more abundant returns. The last fine shower occurred in 1921, so that if the latter period is admissible there should occur good showers in 1933, 1945, 1956, etc. This system apparently forms a complete ring, but the meteors are evidently more thickly condensed at some points of the orbit than at others.

W. F. Denning.

No. 3067, Vou. 122] 